\title{
Transfer of Knowhow and Experiences from Commercial Logistics into Humanitarian Logistics to Improve Rescue Missions in Disaster Areas
}

\author{
Firas Rifai ${ }^{1}$ \\ ${ }^{1}$ Department of Business Administration, Faculty of Business, Al-Zaytoonah University of Jordan, Jordan \\ Correspondence: Firas Rifai, Department of Business Administration, Faculty of Business, Al-Zaytoonah \\ University of Jordan, P. O. Box 130, Amman 11733, Jordan.
}

Received: June 4, 2018 Accepted: June 22, $2018 \quad$ Online Published: August 21, 2018

doi:10.5539/jms.v8n3p63 URL: https://doi.org/10.5539/jms.v8n3p63

\begin{abstract}
Reports on the news about nature or man-made catastrophes are not uncommon. We hear constantly that a human catastrophe has taken place somewhere in the world. In those cases where the infrastructure could possibly be destroyed, it becomes clear that a rescue mission is difficult to achieve. We need special rescue teams, who despite the difficult rescue mission, save lives and reduce suffering.

The special organizations involved in catastrophes are called humanitarian organizations. In addition, the specific skills and abilities that these organizations have should be mainly in logistics.

In this paper, the author goes into more details about humanitarian logistics and shows its importance in disaster areas. Unfortunately, these humanitarian organizations have many weaknesses and challenges. As a result, these organizations are not well developed, despite their importance. In contrast, the commercial logistics companies, which are well developed, have much strength in management, information technologies, etc.

This research defines humanitarian logistics and describes its weaknesses and limitations. Furthermore, it deals with the specifics of humanitarian organizations. The special features of these organizations are their rescue missions, especially in destroyed infrastructure areas. This research demonstrates the various similarities between commercial and humanitarian logistics and points to the potential of knowledge and experience transfer from commercial logistics to humanitarian logistics.

This research compares humanitarian logistics with commercial logistics. In doing so, the author tries to gain a deeper insight into the potential of transferring know-how and experience from retail logistics to humanitarian logistics in order to strengthen humanitarian logistics.

The research of logistics is a very dynamic world in which humanitarian logistics is becoming increasingly important both in research and in practice. In particular, the demands on logistics in general and on humanitarian logistics, in particular, will increase significantly in the near future because it is estimated that the number and impact of both natural and human disasters is increasing (Kumar et al., 2012).

Murphy (2015) analyzed the past data of catastrophes and derived a forecast for the future frequency of disasters and their impact: "Because of the increasing frequency (and severity) of disasters over the past 50 years, humanitarian logistics is likely to be an important topic into the foreseeable future".
\end{abstract}

Keywords: know how transfer, commercial logistics, humanitarian logistics, rescue mission, disaster areas

\section{Introduction}

We hear repeatedly about difficult rescue missions or failed rescue missions. The complicated and difficult rescue missions mostly relate to destroyed infrastructure. The failed rescue missions are mostly due to a lack of expertise in logistics. Despite the great importance of humanitarian logistics companies, this area remained underdeveloped.

The importance of this study is that humanitarian logistics is greatly enhanced and strengthened through the use of commercial logistics experience. Improving humanitarian logistics means saving more human lives. This topic should be given more attention because it is becoming increasingly important and it is about saving lives. 
Particularly in the Arab countries, where there are wars and political unrest, well-developed humanitarian logistics is strongly needed.

The number of disasters has increased dramatically since the $70 \mathrm{~s}$ of the last century. This led, in addition to the losses in economic and social life, to high numbers of victims and dead. In 2010 alone, a total of more than 300 disasters occurred. About $50 \%$ of these disasters were natural (earthquakes, floods, storms, landslides, droughts and volcanic eruptions) and 50\% were man-made (wars, political, terrorist and armed conflicts, civil war and technological events due to biological, chemical and nuclear events such as oil spills) (Bevere et al., 2011).

Despite the increase in environmental disasters, logistics experts are focusing heavily on the commercial sector. Humanitarian logistics is largely carried out by aid organizations without special logistical skills (Baumgarten, 2010). It should be noted that humanitarian logistics is more expensive than commercial logistics (Thomas \& Kopczak, 2005; Wilhaus, 2010).

In this context, it should be mentioned that humanitarian aid requires effective and efficient logistical handling of relief efforts, because the goal of humanitarian logistics is to save lives. That's why logistics is an essential factor for any company. The special importance of logistics and a smooth logistical process will be more important, especially for humanitarian organizations.

Humanitarian logistics is no different from the other areas of logistics, such as commercial leagues. Humanitarian logistics covers all traditional logistics activities for emergency aid projects in crisis and conflict regions with a focus on water, food, housing, primary health care, basic infrastructure, training, etc. (Blecken 2006 \& 2010).

Rescue missions require people with experience in logistics or supply chain. These so-called supply managers are urgently needed to improve the overall rescue mission, achieve overall goals and save lives. Although the work and experience of these managers do not bring any profit, they do much to protect people's lives and reduce their suffering.

The entire rescue mission faces several challenges in humanitarian logistics: humanitarian coordination, performance measurement, efficiency measurement, humanitarian supply chain design, humanitarian aid material flow control, short delivery times, delivery of the right goods in the shortest possible time, transport modeling, network modeling and design, and distribution and human resources procurement logistics. Just like the importance of humanitarian logistics, it will be very important to eliminate all these issues and problems (Beamon \& Balcik, 2008; Kovacz \& Spens, 2007; Kovacz \& Tatham, 2008; Bölsche, 2009; Gatignon et al., 2010; Tunfinkgi, 2006; Kovacz \& Spens, 2009).

With every new disaster or catastrophe, the importance of humanitarian logistics is growing. Humanitarian logistics is gaining in importance over time and rapidly. It is developing into an important future field worldwide, especially in catastrophic areas (Baumgarten, 2010).

In 2004 the Tusnami in the Indian Ocean hit many countries in south west asia and killed hundert thausand person and millios others became homeless. This huge natural disaster showed clearly the wealnesses and problems in the performance of relief operations. This disaster and weak performance in humanitarian logistics caused a serie of worldwide outcries for improved logistics in humanitarian relief operations. Since then Humanitarian Logistics seems to have gained more interests in both; in academia and in practice. What we really need are people to sort goods, identify priorities, track deliveries, and direct the traffic of a relief effort in full gear" (Russell, 2005).

The interest in mass human rescue is increasing during the second world war. At that time, the goal was; to relocate millions of war and homeless people. This led to the founding of "the United Nations Refugee Relief Administration (UNRRA)".

Batta and Mannur (1990), Sherali et al. (1991), Long and Wood (1995), Haghani and Oh (1996), Pidd, de Silva and Eglese (1996), Wu, Wein and Perelson (2005) as well as Larson (2007) have many suggestions for improving relief operations, improved response to disease outbreaks and emergencies, etc. in their theoretical and academic endeavors.

Despite the growing interest in humanitarian logistics, this area is still considered weak. There is still a great need for further improvement measures.

These measures are to be made especially in the area of various logistics tasks and the application of new technologies. In this matter, commercial logistics is considered very developed and has many important experiences and specific know-how. This accumulated knowledge and know-how should be transferable to humanitarian logistics. 


\section{Commercial vs. Humanitarian Logistics: Definitions and Tasks Comparison}

There are many different definitions of logistics in literature. All definitions have more or less shown the same definition for logistics. That is why we will define the term logistics only a single time.

Van Wassenhove defined logistics as "processes and systems for mobilizing people, resources, skills and knowledge to help people affected by natural disasters or man-made disasters" (Van Wassenhove, 2006). What exactly is the logistics in disasters times actually "to locate, collect, transport and distribute food and medical materials earlier and later" (Murphy, 2015).

With regard to the application of logistics, Thomas 2003 saw logistics as the main factor in human life-saving missions. Thomas cited many reasons for the importance of logistics in catastrophe areas and in humanitarian rescue missions.

\section{1- Logistics takes a key position between}

a) Disaster preparedness and response,

b) Procurement and distribution, as well as between,

c) Central office and targeted areas.

2- Logistics has a major impact on the effectiveness and speed of response of various and very important humanitarian programs such as health, food, housing, water and sanitation.

3- Logistics handles the goods through the supply chain and it is also considered as a relevant databank that can be analyzed and used to gain new knowledge.

This logistics data, which is analyzed, includes conclusions about the effectiveness of suppliers and transport providers, the cost and timeliness of the response and other important information. Therefore, this data is of great importance for the improvement of all logistical services (Thomas, 2003).

Murphy (2015) regards logistics management, especially commercial logistics management, as an important part of supply chain management (SCM), which involves the efficient, efficient flow and return and storage of goods, services and information throughout the entire process (from warehouse to warehouse) Customer.

Despite the consistency of humanitarian and commercial logistics, profit-seeking is the main difference between both types of logistics, with commercial logistics targeting profit maximization. In terms of the logistics process, Thomas (2003) defines humanitarian logistics based on the processes and systems as follows; Humanitarian logistics refers to mobilizing people, resources, skills and knowledge to help vulnerable people affected by natural disasters and complex emergencies. In addition, humanitarian logistics includes a range of activities such as procurement, transportation, tracking and tracing, customs clearance, local transportation, warehousing and last-mile delivery (Thomas, 2003).

At the center of this consideration are both commercial and humanitarian logistics. The possibility of transferring knowledge from commercial to humanitarian logistics is being investigated. This project concerns the transfer of know-how and experience from the widespread commercial logistics to the very important humanitarian logistics. In order to transfer experiences from commercial logistics to humanitarian logistics, we have to show the interfaces between the two areas. The following factors are common in both commercial logistics (supply chain) and humanitarian logistics as a supply chain:

Table 1. Comparison between commercial \& humanitarian logistics (1)

\begin{tabular}{lll}
\hline & Commercial Log. & Humanitarian Log. \\
\hline Supply: meet customer needs & defined specification & undefined specification \\
Inventory (2) & manageable & difficult to manage \\
difficult - destroyed infrastructure \\
Distribution & easy & uncertainty in procurement and demand \\
Flow & match supply with demand & longer than C. Logistics \\
Lead Time & shorter than H. Logistics & manual process \\
Information System (3) & good information management & problematic customer responsiveness \\
Customer (4) & planned customer responsiveness & lack in demand data \\
Demand & known requirements, quantity, and location & minimize loss of life \\
Objective (5) & maximize profit & essential - not stabile demand and supply \\
Agility (6): response to fluctuation & relative stability in demand and supply & difficult but important adaptability \\
Adaptability (7) & high adaptability to changing environment & very important \\
Alignment: goals of partners & Important & from case to case \\
Performance Measure (8) & predominantly used & \\
\hline
\end{tabular}

Notes. 1- (Gustavsson, 2002), 2- (Maspero \& Ittmann, 2008), 3- (Thomas \& Kopezak, 2007),

4- (Oloruntoba \& Gray, 2006) and (VanWassenhove, 2006), 5- (Thomas, 2003) and (VanWassenhove, 2006),

6- (Lee, 2006) and (Maskell, 2001), 7- (Lee, 2006), (Beamon, 1999), 8- (Beamon, 1999). 
In this context, it does not really matter, whether it's humanitarian or commercial logistics. Logisticians, in general, aim to ensure that the customer (commercial or humanitarian) get the right support, at the right time and at the right cost. These challenges are manifold and complex (Gustavsson, 2002).

This chart compares commercial logistics with humanitarian logistics. This comparison was based on the following factors: Supply, Inventory, Distribution, Flow, Lead Time, Information System, Customer, Demand, Objective, Agility, Adaptability, Alignment and Performance Measure.

It can be clearly seen that the two disciplines are following similar goals and target satisfy customers. In commercial logistics, customers are supplied with goods that best meet their needs. In humanitarian logistics, the customer is supplied with goods that improve his or her critical situation or even get the customer out of a ruined area.

The strong similarity of both disciplines allows an effective transfer of knowledge between both disciplines, and especially commercial ones in humanitarian logistics.

\section{Literature Review}

Despite the importance of humanitarian logistics, it is very little present in literature and scientific publications. It should be noted that the great research interest is focused on commercial logistics. This topic has been thoroughly investigated and taken on several perspectives (Abidi \& Klumpp, 2011; Altay \& Green, 2006).

Why humanitarian logistics has attracted little interest. There are many reasons for this research gap; on the one hand because of the low interest of the company and on the other because the fact that humanitarian logistics cannot generate profits (Abidi \& Klumpp, 2011).

Only after the failures of the rescue missions and the logistical missions during the tsunami disaster in 2004 did this important field of humanitarian logistics become known and attracted interest (Heaslip, 2008).

In 2006, during the development efforts of humanitarian logistics, "Van Wassenhove" investigated both logistics, commercial logistics and humanitarian logistics. He developed a model of how logistics can be effectively designed in the event of a disaster.

Wassenhove's model consists of five elements:

- Human resources,

- Knowledge,

- Business Administration,

- Finances and

- Society (Wassenhove, 2006).

In the same period of Wassenhove's model, Olortunba and Gray 2006 also developed another model that depicts the agile supply chain for the humanitarian sector (Abidi \& Klumpp, 2011). One year later, Kovacs and Spens compared humanitarian and commercial logistics. They provided recommendations and suggestions to transfer the necessary knowledge from commercial logistics to humanitarian logistics (Kovacz \& Spens, 2007). Then, in 2009, years and Jensen created a model that identifies valuable knowledge and experience from commercial logistics and verifies their transfer to humanitarian logistics (Jahre, Jensen, \& Lisou, 2009).

Davidson (2006) and Beamon \& Balcik (2008) focused on efficiency measurement in humanitarian logistics. Beamon \& Balcik compared the methods of efficiency measurement in commercial and humanitarian logistics. In 2008, Beamon \& Balcik also developed a model for the effective storage of humanitarian supplies. The distribution of these supplies to those in need was reported by Vitoriano et al. examined in 2010. Vitoriano develops a mathematical distribution model. Intensive comparisons between humanitarian and commercial logistics were made in 2003 by Thomas, in 2004 by Beamon, and in 2009 by Aslanzadeh et al. carried out. 
Table 2. Summary on literature review

\begin{tabular}{|c|c|}
\hline Author / Year & Contribution \\
\hline Thomas, 2003 & $\begin{array}{l}\text { He intensive compares between humanitarian and commercial } \\
\text { logistics. }\end{array}$ \\
\hline Altay \& Green, 2006 & $\begin{array}{l}\text { They investigate why research is focusing on commercial } \\
\text { logistics and less on humanitarian Logistics. }\end{array}$ \\
\hline Olortunba \& Gray, 2006 & $\begin{array}{l}\text { He developed a model that depicts the agile supply chain for } \\
\text { the humanitarian sector }\end{array}$ \\
\hline Davidson, 2006 & $\begin{array}{l}\text { They focused on efficiency measurement in humanitarian } \\
\text { logistics. }\end{array}$ \\
\hline Kovacz \& Spens, 2007 & $\begin{array}{l}\text { They provided recommendations and suggestions to transfer } \\
\text { the necessary knowledge from commercial logistics to } \\
\text { humanitarian logistics. }\end{array}$ \\
\hline Van Wassenhove, 2008 & $\begin{array}{l}\text { He developed a model of how logistics can be effectively } \\
\text { designed in the event of a disaster. }\end{array}$ \\
\hline Heaslip, 2008 & $\begin{array}{l}\text { He noted the increasing interest on humanitarian logistics after } \\
\text { the failures of the rescue missions during the tsunami disaster } \\
\text { in } 2004 \text {. }\end{array}$ \\
\hline Beamon \& Balcik, 2008 & $\begin{array}{l}\text { They compared the methods of efficiency measurement in } \\
\text { commercial and humanitarian logistics. }\end{array}$ \\
\hline Beamon \& Balcik, 2008 & $\begin{array}{l}\text { They developed a model for the effective storage of } \\
\text { humanitarian supplies. }\end{array}$ \\
\hline Jahre, Jensen, \& Lisou, 2009 & $\begin{array}{l}\text { They created a model that identifies valuable knowledge and } \\
\text { experience from commercial logistics and verifies their } \\
\text { transfer to humanitarian logistics. }\end{array}$ \\
\hline Vitoriano, 2010 & He develops a mathematical distribution model. \\
\hline
\end{tabular}

\section{Supply and Demand in the Context of Catastrophen and Humanitären Logistics}

\subsection{Supply}

In catastrophes cases of humanitarian logistics, supply is limited to certain items such as relief supplies, personnel, transport and construction materials, most of which are donated. Because of this, specific challenges would arise:

1 - There is uncertainty as to whether or not we will receive adequate donation

2- Timing of deliveries poses a potential problem: for example, goods that arrive too early and are not stored for long.

\subsection{Demand}

The needs of affected people change significantly after a disaster. Many factors play a role in the composition of demand, which are difficult to measure and have high levels of uncertainty. Unlike private sector logisticians, humanitarian workers are always confronted with the unknown: when, where, what, how much, where and how often. The basic parameters needed to efficiently build the supply chain are highly uncertain (Van Wassenhove, 2006). The demand for disasters is also difficult due to the lack of historical data.

\section{International Humanitarian Organization}

As previously stated and based on the general tasks of logistics, (international) humanitarian organizations contribute to the rapid and efficient provision of humanitarian aid in the event of (long-term) natural or human disasters. In this context, these (international) humanitarian organizations are considered the biggest players in the world. Over time, these organizations accumulated sound expertise, detailed knowledge of specific local areas, and the ability to provide the right help to the most vulnerable populations. (Ministry of Foreign affairs of Denmark (2018).

Humanitarian organizations that focus on minimizing loss of life and alleviating suffering are very important players that governments rely on and support (Financing International Humanitarian Action, 2002).

In addition to government support to the various humanitarian organizations, there is also great support in the form of donations from foundations, individuals and the private sector (Thomas, 2003). 
The tasks that global humanitarian organizations undertake are mostly development and assistance activities, and are mostly related to emergency food, shelter and services available immediately after a natural disaster or man-made disaster (Thomas, 2003).

The main problem in humanitarian logistics is to coordinate the flow of goods or services with the appropriate flow of information and communication flows at the right time, in the right amount, in the right place, in the right quality, and at the right price. In order to strengthen the cooperation and performance of various international organizations, global players such as the "International Federation of Clusters" have been merged.

Below are the main international organizations active in this cluster:

- $\quad$ Red Cross (www.icrc.org) www.df.de

- $\quad$ Red Crescent Societies (IFRC) (www.ifrc.org),

- UN World Food Programme (WFP) (www1.wfp.org),

- United Nations International Children's Emergency Fund (UNICEF) (www.unicef.org),

- World Health Organization (WHO) (www.who.int),

- United Nations Development Programme (UNDP) (www.undp.org),

- $\quad$ United Nations High Commissioner for Refugees (UNHCR) (www.unhcr.org) und

- International Organization for Migration (IOM) (www.iom.int)

The problems of the international humanitarian organizations led to the creation of this cluster. Most of the problems that are being addressed by this cluster are general inefficiencies and, in particular, slow responses to the humanitarian crisis. In fact, this cluster has improved the overall performance of humanitarian organizations. This cluster strengthened the response capacity, improved coordination and accountability by strengthening partnerships in key sectors. By formalizing the leadership role of specific organizations in each of the following sectors:

1) Cleanliness,

2) Protection,

3) Accommodation,

4) Nutrition,

5) Health,

6) Emergency Telecommunications,

7) Education, Quick Recovery,

8) Rapid Recovery and

9) Coordination of all logistical plans and services (Logistics Cluster 2018).

This coordination and information management offered by this cluster helps humanitarian organizations make operational decisions. In addition, this coordination effort seeks to improve the predictability, timeliness and efficiency of humanitarian emergency response. This cluster also facilitates access to shared logistics services for all member organizations. This logistics cluster is a mechanism of the Inter-institutional Standing Committee (IASC) with the purpose of humanitarian coordination. This cluster was adopted in 2005 with the overall objective of improving the performance of humanitarian aid worldwide (Logistics Cluster 2018).

This coordination concept (cluster) was developed after the tsunami in 2004 and further developed after Hurricane Katrina in 2005. The main objective of this cluster is to eliminate the weak point of coordination of the various logistics companies and to increase the overall performance of these organizations (Wassenhove et al. 2010).

In July 2006, the supply chain was decentralized. There were 3 different large warehouses located in Kuala Lumpur, Dubai and Panama.

A- The warehouse in Kuala Lumpur supplies Asia and Australia,

B- The warehouse in Dubai is located near the seaport and the airport and carries 12 million tons annually. It supplies Europe, the Middle East and Africa.

C- The warehouse in Panama, on the other hand, supplies America with relief supplies. 
The efficiency of these warehouses is great; all three warehouses can deliver relief supplies to 34,000 families within 48 hours, or each camp can help 5,000 families and support them relatively very fast (Thomas 2003).

There are many tasks that arise on such warehouses. The most important tasks that a warehouse undertakes are, for example, delivery, mobilization of the helper teams, procurement, storage and fleet management (Olsen 2007). The mobilization tasks in general include creation of relevant plans specifying the need for goods, the required quantity, and the name of the donor and the description of the aid. These mobilization plans support the use of the so-called pull strategy: according to this strategy, unnecessary goods are not delivered to the needy and the limited storage capacity is well utilized. In this strategy, the needs of the needy are identified and purchased. This procedure serves to maximize the effectiveness and efficiency of humanitarian assistance (IFRC 2006), (Gatignon et al. 2010).

\section{Obstacles in Know-How Transfer from Commercial to Humanitarian Logistics}

When comparing humanitarian logistics with commercial logistics, we see many similarities, so it could be said that experience in one particular logistics area is transferable and useful to other areas of logistics.

Actually, it is different. In most cases, experience from the corporate world (commercial logistics) is not transferred to other fields such as humanitarian logistics. This raises the question as to how it can be that such a very important sector (humanitarian logistics), which must always be up to date and make a very important contribution to human life, is so poorly developed.

In order to be able to transfer know-how and experience from one logistics area to another area, we must identify the main tasks in both areas in order to determine the interfaces between the two areas (commercial and humanitarian).

In 2009, McLachlin differentiated both the tasks and the objectives of the two areas: commercial logistics aims at maximizing profits and can't operate in a devastated disaster area. The commercial logistics operators are supplied with capital goods, finished goods, consumer goods and services for the creation of service processes (Mc Lachlin et al., 2009).

Unlike commercial logistics, the goal in humanitarian logistics is not to maximize profit but to save lives, to help the suffering people, and to help and support the needy with supplies such as medicines, clothing, food, shelter, water, electricity and knowledge (Thomas, 2003) and (Mc Lachlin et al., 2009).

It is easy to imagine what the situation in the disaster area is like. The situation immediately after a catastrophic event is mostly destructive. When the humanitarian workers arrive, the conditions, under which they must work, are extremely chaotic. The most affected infrastructure is the physical one such as roads, bridges and airports. Therefore, the transportation capacity is extremely limited or absent (Thomas, 2003).

Of the many differences between commercial and humanitarian logistics are the lack of logistics structure and distribution network. These serious differences pose a multitude of challenges for humanitarian logistics. Another problem and challenge is the lack of cooperation and coordination along the entire humanitarian logistics chain.

The following are the main obstacles to cooperation and coordination along the entire humanitarian logistics chain. (Thomas, 2003; Howden, 2009; Beamon, 2004; Van Wassenhove, 2006):

1) The flow of information along the entire logistics chain is weak and not sufficiently developed;

2) The transport infrastructure is underdeveloped;

3) The demand for relief supplies is fluctuating and can be difficult to predict;

4) Due to the lack of warehouses and transport capacities, demand is usually difficult to cover;

5) The logistics chain itself is uncoordinated;

6) The competitive situation between relief organizations is becoming more intense;

7) Weak preparatory work for a disaster;

8) The delivery of relief supplies can't be followed smoothly due to a lack of suitability;

9) Lack of experienced logisticians.

At a meeting in Geneva in January 2003, the heads of leading logistics HROs (Human Resources Offices) expressed their frustration with "five butts" that hinder progress in humanitarian logistics:

1) The nature of the financing process: Here it is checked whether the use of funds with earmarking donations for special relief measures are sounding. 
2) Organizational culture and high employee turnover: A well-known feature of humanitarian organizations is the high employee turnover in these organizations.

3) Lack of institutional learning. The humanitarian team will be assigned to the next mission as soon as a crisis is resolved. It would be better for these teams to take the time to reflect and write reports on the last mission and provide ratings with suggestions for improvement.

4) Little collaboration: After a successful mission, done in the most adverse and extreme circumstances, you will be able to transfer your experiences from one catastrophe to the next. The fact is that these valuable experiences are lost.

5) Effective use of technology: humanitarian organizations mostly do not use existing technologies effectively (Thomas, 2003).

We all know how quickly the environment in the technological sector is changing. Today, modern technology offers greatly improved approaches to logistics and supply chain management and better access to know-how and information. This is crucial for NGOs and opens the way for the transfer of knowledge between the different areas of logistics. Nevertheless, this technology encounters obstacles that will not be discussed further here (Gustavsson, 2002).

In order to improve the performance of humanitarian logistics and to be able to transfer know-how and experiences from commercial logistics into humanitarian logistics there are many recommendations as follow:

1) Needs analysis. This analysis should be based on historical data, past experience and most likely scenarios,

2) Inventory planning and control. This can shorten delivery times and optimize it,

3) Regional coordination and synergies through process standardization. Here, the strengths of the various organizations can be bundled and optimized,

4) Donation management - Donations should be bundled together so that they can have a strong impact,

5) Cooperation between organizations. Governments should play a leading role and better coordinate their work and, if necessary, achieve synergy effects,

6) Understanding the regional political, economic and socio-economic conditions: It is certainly very important to raise awareness of local conditions, because this awareness is crucial to the success of humanitarian missions.

7) Use of local capacities and capabilities, ask the question: what capacities are available in the local place? The use of local capacities and resources such as volunteers, pack animals, carts, etc. provides the added benefit.

8) Constant communication: Sharing information with people in disaster areas is crucial, so information and communication emergencies systems should be built in advance.

9) Socio-economic impact assessment: As it is possible to have negative socio-economic impacts of humanitarian action, past experience and exchange of information could be helpful in reducing this impact.

10) Evaluation of humanitarian operations: We can always improve humanitarian operations by discussing and documenting all the lessons learned after a disaster (Ergun et al., 2010).

On the above recommendations, Gustavsson (2002) added 3 important points that need to be done to improve humanitarian logistics:

- Expand relevant knowledge,

- Expand funding sources,

- Increase investment in technology and communication (Gustavsson, 2002).

\section{Summary and Conclusion}

The aim of the comparison of humanitarian logistics with commercial logistics is to provide the humanitarian logistics with advanced knowledge and experiences that accumulated in in the field of the commercial logistics. This Knowledge transfer from commercial logistics into humanitarian logistics accelerates the development process within the humanitarian logistics.

Furthermore the author tried to create an understanding between the two sides and to identify opportunities for further synergy between them. 
Humanitarian logistics is considered as part of a (humanitarian) supply chain and associated (humanitarian) activities. Without a functioning and efficient logistical organization of the processes, aid in the disaster area would be cost-intensive.

The objectives of humanitarian and commercial logistics, represented by the qualitative and quantitative characteristics, show that humanitarian logistics will develop into a separate area.

\section{References}

Abidi, H., \& Klumpp, M. (2011). Humanitarian Logistics versus commercial Logistics. Institut für Logistik- \& Dienstleistungsmanagement (ild), FOM Hochschule für Oekonomie \& Management.

Altay, N., \& Green III, W. G. (2006). OR/MS research in disaster operations management. European Journal of Operational Research, 175(1), 475-493. https://doi.org/10.1016/j.ejor.2005.05.016

Aslanzadeh, M., Rostami, E. A., \& Kardar, L. (2009). Supply Chain and Logistics, Berlin Heidelberg.

Batta, R., \& Mannur, N. R. (1990). Covering-Location models for Emergency Situations that Require Multiple Response Units. Management Science, 36(1), 16-23. https://doi.org/10.1287/mnsc.36.1.16

Baumgarten, H. (2010). Schnelle Hilfe im Katastrophenfall. Retrieved from http://www.handelsblatt.com/unternehmen/handel-dienstleister/schnelle-hilfe-imkatastrophenfall/3630214.h tml

Baumgarten. (2010). Humanitarian $\quad$ Logistics. $\quad$ Retrieved from www.bvl.de/Wissenschaft--Forschung/Arbeitskreise/Humanitaere-Logistik/Videos/Interview-Baumgarten

Beamon, B. M. (1999). Measuring supply chain performance. International Journal of Operations \& Production Management, 19(3), 275-292. https://doi.org/10.1108/01443579910249714

Beamon, M. B. (2004). Humanitarian Relief Chains: Issues and Challenges. In 34th International Conference on Computers and Industrial Engineering, San Francisco, CA, USA.

Beamon, M. B., \& Balcik, B. (2008). Performance measurement in humanitarian relief chains. International Journal of Public Sector Management, 21(1), 4-25. https://doi.org/10.1108/09513550810846087

Beamon, M. B., \& Kotleba, S. A. (2006). Inventory management support systems for emergency humanitarian relief operation in South Sudan. International Journal of Logistics Management, 17(2), 187-212. https://doi.org/10.1108/09574090610689952

Bevere, L., Rogers, B., \& Grollimund, B. (2011). Natural catastrophes and man-made disasters in 2010: a year of devastating and costly events. Retrieved from www.swissre.com/publications/

Blecken, A. (2006). Humanitäre Logistik. Universität Paderborn, Heinz Nixdorf Institut. Retrieved from http://www.hni.uni_paderborn.de/fileadmin/hni-cim/Lehre/W4331/AB-W4332-Seminar_und_Projekttheme n_VZ.pdf

Blecken, A. (2010). Humanitarian Logistics. Modelling Supply Chain Process of Humanitarian Organisations, Bern.

Bölsche, D. (2009). Internationales Katastrophenmanagement. Logistik und Supply Chain Management, Baden. https://doi.org/10.5771/9783845213101

Davidson, A. L. (2006). Key Performance Indicators in Humanitarian Logistics. Master Thesis, Massachusetts Institute of Technology, Boston.

Ergun, Ö., Keskinocak, P., Swann, J., Heier Stamm, J. L., \& Villarreal, M. (2010). Relief Operations: How to Improve Humanitarian Logistics. Analytics: Driving better business decisions. Retrieved from http://analytics-magazine.org/relief-operations-how-to-improve-humanitarian-logistics/

Financing International Humanitarian Action. (2002). A Review of Key Trends, Humanitarian Policy Group briefing paper, November 2002.

Gatignon, A., Van Wassenhove, L. N., \& Charles, A. (2010). The Yogyakarta earthquake: Humanitarian relief through IFRC's decentralized supply Chain. International Journal Production Economics, 126, 102-110. https://doi.org/10.1016/j.jpe.2010.01.003

Gustavsson, L. (2002). Humanitarian logistics: context and challenges, Logistics and supply chain management underpin responses to humanitarian crises. 
Haghani, A., \& Oh, S.-C. (1996). Formulation and Solution of a Multi-Commodity, Multi-Modal Network flow Model for Disaster Relief Operations. Transportation Research A, 30(3), 231-250. https://doi.org/10.1016/0965-8564(95)00020-8

Heaslip, G. (2008). Humanitarian aid supply chains. In J. Mangan, C. Lalwani, \& T. Butcher (Hrsg.), Global Logistics and Supply Chain Management. Chichester: John Wiley \& Son.

Howden, M. (2009). How Humanitarian Logistics Information Systems Can Improve Humanitarian Supply Chains. In A View from the field. In 6th International ISCRAM Conference- Gothenburg, Sweden.

IFRC. (2006). International Federation of Red Cross and Red Crescent Societies, IFRC Information Bulletin, April 2006. Retrieved from http://media.ifrc.org/ifrc/

International Organization for Migration (IOM). (2018). Retrieved from www.iom.int

Jahre, M., Jensen, L. M., \& Lisou, T. (2009). Theory development in humanitarian logistics: a framework and three cases. Management Research News, 32(11), 1008-1023. https://doi.org/10.1108/01409170910998255

Kovacz, G., \& Spens, K. M. (2007). Humanitarian Logistics in disaster relief operations. International Journal of Physical Distribution \& Logistic Management, $37(2), \quad 99-114$. https://doi.org/10.1108/09600030710734820

Kovacz, G., \& Spens, K. M. (2009). Identifying challenges in humanitarian logistics. International Journal of $\begin{array}{llll}\text { Physical Distribution \& Logistics } & \text { Management, }\end{array}$ https://doi.org/10.1108/09600030910985848

Kovacz, G., \& Tatham, P. (2008). Humanitarian logistics performance in the light of gender. International Journal of Productivity and Performance Management, 58(2), 174-187. https://doi.org/10.1108/17410400910928752

Kress, M. (2002). Operational Logistics: The Art and Science of Sustaining Military Operations. Boston: Kluwer Academic Publishers. https://doi.org/10.1007/978-1-4615-1085-7

Kumar, A., Latif, Y. L. A., \& Daver, F. (2012). Developing Forecasting Tool for Humanitarian Relief Organizations in Emergency Logistics Planning. World Academy of Science, Engineering and Technology. International Journal of Social, Behavioral, Educational, Economic, Business and Industrial Engineering, $6(11)$.

Larson, R. C. (2007). Simple models of influenza progression within a heterogeneous population. Operations Research, 55(3), 399-412. https://doi.org/10.1287/opre.1070.0399

Lee, H. L. (2006). The triple-A supply chain. Harvard Business Review on Supply Chain Management, pp. $87-115$.

Logistics Cluster. (2018). Retrieved from www.logcluster.org

Long, D. C., \& Wood, D. F. (1995). The logistics of famine relief. Journal of Business Logistics, 16(1), 213-229.

Maskell, B. (2001). The age of agile manufacturing. Supply Chain Management: An International Journal, 6(1), 5-11. https://doi.org/10.1108/13598540110380868

Maspero, E. L., \& Ittmann, H. W. (2008). The rise of humanitarian logistics. Proceedings of the 27th Southern African Transport Conference, pp. 175-184, July 2008.

Mc Lachlin, R., Larson, P. D., \& Khan, S. (2009). Not-for-profit supply chain in interrupted environments: the case of a faith-based humanitarian relief organization. Management Research News, 32(11), 1050-1064. https://doi.org/10.1108/01409170910998282

Ministry of Foreign affairs of Denmark. (2018). International Humanitarian Organisations. Retrieved from http://um.dk/en/danida-en/partners/humanitarian-organisations/international-humanitarian-organisations/

Murphy, Jr., Paul R., \& Knemeyer, A. M. (2015). Contemporary Logistics (11th ed.). Pearson Education, Inc.

Oloruntoba, R., \& Gray, R. (2006). Humanitarian aid: an agile supply chain? Supply Chain Management: An International Journal, 11(2), 115-120.

Olsen, B. (2007). IFRC Performance measurement. Retrieved from www.fritzinstitute.org/PDFs/Programs/HLC2007/HLS_IFRC.pdf

Pidd, M., de Silva, F. N., \& Eglese, R. W. (1996). A simulation model for emergency evacuation. European Journal of Operational Research, 90(3), 413-419. https://doi.org/10.1016/0377-2217(95)00112-3 
Red Crescent Societies (IFRC). (2018). Retrieved from www.ifrc.org

Red Cross. (2018). Retrieved from www.icrc.org

Russell, T. (2005). The Humanitarian Relief Supply Chain: Analysis of the 2004 South East Asia Earthquake and Tsunami. Master of Engineering in Logistics Thesis, MIT.

Sherali, H. D., Carter, T. B., \& Hobeika, A. G. (1991). A Location-Allocation Model and Algorithm for Evacuation Planning under Hurricane/Flood Conditions. Transportation Research Part B, 25(6), 439-452. https://doi.org/10.1016/0191-2615(91)90037-J

Thomas, A. (2003). Humanitarian logistics: Enabling disaster response. Fritz Institute, p. 15.

Thomas, A. S., \& Kopczak, L. R. (2005). From Logistics to Supply Chain Management: The path Forward in the humanitarian sector. Retrieved from www.fritzinstitute.org/PDFs/WhitePaper/Fromlogisticsto.pdf

Thomas, A., \& Kopezak, L. R. (2007). Life-saving supply chains: Challenges and path forward. In H. L. Lee \& C. Y. Lee (Eds.), Building Supply Chain Excellence in Emerging Economies. New York: Springer Science. https://doi.org/10.1007/978-0-387-38429-0_4

Tunfinkgi, P. (2006). Logistik im Kontext internationaler Katastrophenhilfe: Entwicklung eines logistischen Referenzmodells für Katastrophenhilfe, Haupt Verlag.

UN OCHA. (2011). Klibi, E., Telefoninterview am 25.03.2011.

UN World Food Programme (WFP). (2018). Retrieved from www1.wfp.org

United Nations Development Programme (UNDP). (2018). Retrieved from www.undp.org

United Nations High Commissioner for Refugees (UNHCR). (2018). Retrieved from www.unhcr.org

United Nations International Children's Emergency Fund (UNICEF). (2018). Retrieved from www.unicef.org

Van Wassenhove, L. N. (2006). Humanitarian aid logistics: supply chain management in high gear. Journal of the operational Research Society, 57, 475-489. https://doi.org/10.1057/palgrave.jors.2602125

Van Wassenhove, L. N., Martinez, P., \& Stapleton, A. J. (2010). An analysis of the relief supply Chain in the first week after the Haiti Earthquake. Insead Eigenverlag 2010.

Vitoriano, B., Ortuna, M. T., Tirado, G., \& Montero, J. (2010). A multi-criteria optimization model for humanitarian aid distribution. In Springer Science and Business Media, LLC.

Wilhaus, M. (2010). Schnelle Hilfe im Katastrophenfall. Retrieved from http://www.handelsblatt.com/unternehmen/handel-dienstleister/schnelle-hilfe-imkatastrophenfall/3630214.h tml

World Health Organization (WHO). (2018). Retrieved from www.who.int

Wu, J. T., Wein, L., Perelson, A. S. (2005). Optimization of Influenza Vaccine Selection. Operations Research 53, 456-476. https://doi.org/10.1287/opre.1040.0143

\section{Copyrights}

Copyright for this article is retained by the author, with first publication rights granted to the journal.

This is an open-access article distributed under the terms and conditions of the Creative Commons Attribution license (http://creativecommons.org/licenses/by/4.0/). 